\title{
PENGARUH PROFITABILITAS, STRUKTUR AKTIVA, PERTUMBUHAN PERUSAHAAN, RISIKO BISNIS DAN AKTIVITAS PERUSAHAAN TERHADAP STRUKTUR MODAL
}

\author{
Melinda Rubiyana ${ }^{1}$, Farida Titik Kristanti ${ }^{2}$ \\ Universitas Telkom
}

\begin{abstract}
The purpose of this study is to determine the effect of profitability(ROA), asset structure(SA), company growth (GROWTH), business risk (BEPR), and company activities (TATO) on capital structure (DER) in a large trading sub-sector company listed its shares on the Indonesia Stock Exchange 2013-2018 period simultaneously (simultaneously) or partially (partial). Purposive sampling technique was used in this study for sampling by obtaining 21 company samples with a research period of 6 years, so that 126 data samples were obtained. Processing data using Eviews 9.0, this study uses data from several independent variables, namely profitability (ROA), asset structure (SA), company growth (GROWTH), business risk (BEPR), and company activities (TATO) with the results of research that simultaneously the five independent variables can affect the capital structure. While partially it can be concluded, company growth has a significant negative effect on capital structure and asset structure has a significant positive effect on the dependent variable. Whereas the other variables, profitability, business risk, and company activities cannot influence the capital structure.
\end{abstract}

\section{Keywords $\quad$ : Capital Structure; ROA; SA; GROWTH; BEPR and TATO. \\ Correspondence to : melindarubiyana98@gmail.com}

\section{ABSTRAK}

Tujuan dilakukan penelitian ini yaitu untuk mengetahui pengaruh profitabilitas (ROA), struktur aktiva (SA), pertumbuhan perusahaan (GROWTH), risiko bisnis (BEPR), dan aktivitas perusahaan (TATO) terhadap struktur modal (DER) disuatu perusahaaan sub sektor perdagangan besar yang mencatatkan sahamnya di Bursa Efek Indonesia periode 2013-2018 secara bersamaan (simultan) maupun sebagian (parsial). Teknik purposive sampling digunakan dalam penelitian ini untuk pengambilan sampel dengan peroleh 21 sampel perusahaan dengan periode penelitian 6 tahun, sehingga diperoleh sebesar 126 data sampel. Pengolahaan data menggunakan Eviews 9.0, penelitian ini menggunakan data dari beberapa variabel bebas yaitu profitabilitas (ROA), struktur aktiva (SA), pertumbuhan perusahaan (GROWTH), risiko bisnis (BEPR), dan aktivitas perusahaan (TATO) dengan hasil penelitian bahwa secara simultan kelima variabel bebas tersebut dapat berpengaruh terhadap struktur modal. Sedangkan secara parsial dapat disimpulkan, pertumbuhan perusahaan memiliki sebuah pengaruh negatif signifikan terhadap struktur modal dan struktur aktiva memilki pengaruh positif signifikan terhadap variabel dependen. Sedangkan pada variabel lainnya yaitu profitabilitas, risiko bisnis, dan aktivitas perusahaan tidak dapat mempengaruhi terjadinya struktur modal.

Kata Kunci $\quad$ : Struktur Modal; ROA; SA; GROWTH; BEPR dan TATO.

Korespondensi $\quad:$ melindarubiyana98@gmail.com 


\section{PENDAHULUAN}

Pada dasarnya dalam Perusahaan, keputusan pendanan merupakan aspek yang sangat penting untuk dipertimbangkan. Apabila terjadi keterbatasan dana, maka akan menghambatnya perkembangan perusahaan dan akan berpengaruh terhadap kualitas produk yang dihasilkan. Setiap perusahaan tidak hanya memanfaatkan modal internal baik apabila perusahaan tersebut mendapatkan tambahan modal (modal eksternal) seperti peminjaman dana Perusahaan harus dapat menyeimbangkan penggunaan terhadap modal internal ataupun modal eksternal agar mencapai struktur modal yang optimal(baik) dalam suatu perusahaan. Struktur modal sangat perlu dioptimalkan dikarenakan struktur modal yang baik nantinya akan mempengaruhi terhadap kegiatan operasi yaitu lebih baik pula dalam perusahaan tersebut.

Struktur modal dapat didefinisikan sebagai sebuah perbandingan penggunaan modal asing serta modal sendiri sehingga dapat menghasilkan struktur modal yang optimal yang digunakan untuk membiayai segala aktivitasnya dan belanja perusahaan dalam periode tertentu. Sedangkan defenisi lain struktur modal Menurut (Martono, 2010:240) struktur modal merupakan perbandingan penggunan pendanaan jangka panjang disuatu perusahaan yang ditunjukan dengan hutang jangka panjang terhadap modal sendiri. Tujuan struktur modal yaitu untuk menggabungkan antara berbagai sumber pendanaan yang digunai perusahaan dalam hal untuk membiayai kegiatan operasional dengan menurunkan biaya modal serta dapat meningkatkan harga saham.
Struktur modal ialah variabel terikat dalam penelitian ini dihitung dengan menggunakan rasio solvabilitas. Menurut Kasmir (2010:112) berpendapat bahwa rasio solvabilitas merupakan rasio yang tepat digunakan untuk mengukur struktur modal. DER misalnya yang digunakan untuk menghitung imbangan penggunaan jumlah hutang dengan jumlah modal disuatu perusahaan sub sektor perdagangan besar.

Dalam upaya mewujudkan struktur modal yang optimal disuatu perusahaan, pihak manajer keuangan perlu mempertimbang banyak hal yang dapat memicu struktur modal. Hasil peneliti yang sudah diteliti oleh penulis sebelumnya mengenai faktor yang akan mempengaruhi struktur modal sudah banyak dilakukan. Pada Ariani dan Wiagustini (2017) mengungkapkan bahwa adanya sebuah pengaruh positif signifikan pada variabel profitabilitas. terhadap struktur modal. Firmanullah dan Darsono (2017) mengatakan bahwa stuktur aktiva tidak dapat mempengaruhi terhadap variabel terkait. Salah satu peneliti terdahulu yaitu Suweta dan Dewi (2016) mengungkapkan adanya dampak dari pertumbuhan perusahaan terhadap struktur modal. Menurut Ranti dan Christanti (2017) mengungkapkan bahwa risiko bisnis memiliki pengaruh negatif signifikan terhadap struktur modal. Ismaida dan Saputra (2016) mengungkapkan bahwa aktivitas perusahaan tidak dapat mempengaruhi terhadap struktur modal. Berdasarkan pada pemaparan tersebut, penulis sepakat untuk menguji pengaruh ROA, SA, GROWTH, BEPR dan TATO terhadap variabel terikat yaitu stuktur modal disuatu perusahaaan sub sektor perdagangan 
besar yang mencatatkan sahamnya di BEI periode 2013-2018. Penelitian ini dilakukan untuk mengetahui pengaruh secara bersamaan dan parsial kelima variabel bebas tersebut dapat berpengaruh kepada variabel terikat yaitu struktur modal.



Gambar 1. Nilai Rata-Rata DER Sub sektor Perdagangan Besar

Sumber: data diolah penulis (2020) dari laporan tahunan BEI

Berdasarkan Gambar 1 dapat dilihat bahwa nilai mean dari Debt Equity Ratio (DER) sub sektor perdagangan besar untuk tahun 2013 sampai 2018 mengalami penaikan dan penurunan. Pada tahun 2013 nilai DER sub sektor perdangangan besar ini sebesar 1,45 persen. Pada 2014 mengalami penurunan sebesar 0,57 persen. Pada tahun 2014 mengalami peningkatan sebesar 1,4 persen. Pada tahun 2016 mengalami peningkatan sebesar 1,6 persen. Pada tahun 2017 mengalami peningkatan signifikan sebesar 2,97 persen, tetapi pada tahun 2018 mengalami penurunan kembali sebesar 2,13 persen.

Jika dilihat dari Gambar 1. ada satu tahun dimana perusahaan itu menggunakan hutangnya lebih sedikit daripada modalnya yaitu pada tahun 2014. Dan pada tahun 2013, 2014, 2015 menunjukan hutangnya lebih tinggi daripada modalnya, bahkan pada tahun 2017 menunjukan dimana pengunaan hutangnya lebih tinggi dari modalnya.

Tingginya Debt Equity Ratio (DER) menunjukan bahwa suatu perusahaan tinggi dalam menggunakan hutangnya, hal ini dapat berakibat pada besarnya risiko perusahaan dalam membayar hutang perusahaan tersebut sehingga ini menjadi informasi negatif bagi investor dan apabila suatu perusahaan menghasilkan laba dari kegiatan operasinya, maka laba tersebut akan digunakan untuk membayar hutang perusahaan dibandingkan dengan membagikan dividen kepada para pemegang saham.

Salah satu peneliti terdahulu Kristanti (2009) mengatakan bahwa .perusahaan di Indonesia rata-rata memiliki struktur modal yang tidak konservatif. Sebagian perusahaan yang memiliki keuntungan positif, maka akan menunjukan bahwa perusahaan akan lebih relative efisien dalam menggunakan hutang guna menjalankan operasi mereka.

\section{LANDASAN TEORI}

\section{Struktur Modal}

Menurut

Mardiyanto

(2009)

mengatakan struktur modal dapat didefinisikan sebagai suatu kombinasi kesemibangan dengan hutang jangka panjang dengan modal yang ditetapkan perusahaan, sehingga dapat menghasilkan struktur modal yang optimal guna membiayai operasional mereka dalam periode tertentu.

\section{Teori Modigliani dan Miller}

Dimana dalam teori ini membuat dua persepsi, perspesi yang pertama yaitu dengan tidak adanya pajak, dimana struktur modal tidak berepengaruh pada nilai perusahaan. yang kedua dengan adanya pajak, dalam menggunakn hutang akan meningkatkan nilai perusahaan. Hal tersebut dikarenakan dengan adanya hutang, maka perusahaan tersebut akan menanggung beban pajak yang lebih rendah karena harus membayar bunga atas hutang kepada kreditur.

\section{Teori Trade Off}

Konsep dengan penyeimbangan manfat dan biaya dari penggunaan hutang 
dalam struktur modal suatu perusahaan.

Dengan kata lain suatu perusahaan menggunakan hutang dalam jumlh tertentu agar mencapai struktur modal yang optimal.

\section{Teori Pecking Order}

(Myers, 1984) mengatakan bahwa model struktur pendanaan perusahaan dalam manajemen keuangan, yang pertama diguanakan dari sumber dana terbawah yaitu dana internal.hingga saham sebagai sumber yang terakhir. Dengan kata lain teori Pecking Order merupakan sebuah urutan yang dilakukan perusahaan dalam melakukan pendanaan yang disarankan diambil berdasarkan yang paling rendah risikonya terlebih dahulu sampai yang paling tinggi risikonya, yang pertama yaitu laba ditahan, kedua yaitu pendanaan hutang, dan ketiga yaitu modal.

\section{X1 Profitabilitas \\ Penelitian}

penjelasan pecking ini menggunakan order dimana menjelaskan tentang suatu perusahan akan lebih menggunakan pendanaan yang berasal dari dalam perusahaan terlebih dahulu untuk membiayai pengeluaran modalnya. Hal ini karena tingkat profitabilitas dalam perusahaan tersebut semakin tinggi sehingga menggambarkan bahwa perusahan tersebut mempunyai dana internal yang banyak. Dengan begitu perusahaan dapat mempergunakan dana internal secara berlimpah daripada menggunakan hutang untuk mendukung kegiatan operasional dengan lebih baik. Perusahaan yang memiliki tingka profitabilitas tingi biasanya mengunakan hutang dalam jumlah sedikit. Sehingga dapat dijelaskan bahwa tingginya tingkat profitabilitas, akan menggambarakan hutang semakin rendah. Sa/lah satu peneliti terdahulu Ariani dan Wiagustini (2017) membuktikan adanya bahwa X1 mampu mempengaruhi struktur modal secara negatif $(-)$.

\section{X2 Struktur Aktiva}

Penelitian ini menggunakan teori pecking order sebagai dasar dalam penelitian ini, teori ini menjelaskan bahwa suatu perusahaan akan mempergunakan pendanaan tambhan yang berasal dari luar perusahaan yaitu untuk keperluan investasinya, apabila modal internal dirasa tidak mencukup untuk membiayai operasi perusahaan. Maka perusahaan yang mempunyai SA yang tinggi biasanya menunjukan suatu perusahaan mempunyai aset tetap yang berlimpah sehingga dapat memberikan manfaat tersendiri bagi perusahaan yaitu dapat dijadikan jaminan untk memperoleh hutang. Hal ini dapat diartikan bahwa suatu perusahaan yang mempunyai SA tinggi mempunyai kemudahan dalam berhutang, dibandingkan dengan SA rendah. Sehingga struktur aktiva semakin tinggi, maka hutang semakin tinggi.

Salah satu peneliti terdahulu Suweta \& .Dewi (2016) mengatakan bahwa X2 mampu mempengaruhi struktur modal secara positif $(+)$.

X3 Pertumbuhan Perusahaan

Bagi perusahaan yang akan meningkatkan pertumbuhan perusahaan membutuhkan dana yang besar selain dari modal internal yaitu dengan modal eksternal. Dengan adanya tambahan modal seperti hutang dan saham disuatu perusahaan, maka tambahan dana tersebut akan digunakan untuk meningkatkan perusahaan dari segala aktivitas yang ada dalam perusahaan tersebut. Sehingga pertumbuhan perusahan tinggi maka semakin tinggi hutannya, karena adanya perubahan jumlah aset yang meningkat setiap tahunnya menambah kepercayaan pihak luar kepada 
perusahaan serta mempengaruhi para investor untuk menanmkan modalnya dalam perusahaan itu. Sehingga bagi perusahan yang terdapat tingkat pertumbuhan perusahaan tinggi akan cenderung menggunakan tambahan dana untuk menggerakan kegiatan operasional perusahaan. Dan apabila dana internal tidak mencukupi, hutang menjadi pilihan utama dalam meningkatkan pertumbuhan perusahaan.

Salah satu peneliti terdahulu yaitu Suweta \& Dewi (2016) membuktikan bahwa X3 mampu memberikan pengaruh terhadap struktur modal secara positif $(+)$.

\section{X4 Risiko Bisnis}

Penggunaan hutang sebagai tambahan modal untuk meninggikan aset atau mengerakan kegiatan operasi perusahan tidak boleh sembarangn diambil tetapi harus dilihat risiko bisnis yang ditanggung. Sesuai dengan teori ketiga menjelaskan suatu perusahan akan cenderung menjauhkan hutang apabila dana internal pada perusahaan tersebut dirasa cukup untuk membiayai semua operasional perusahaan. Apabila perusahan memiliki dana internal yang cukup, dengan keadaan keuangan yang stabil serta tidak mengalami ketidakpastian dalam menjalankan bisnisnya, artiya perusahan tidak perlu menggunakan dana yang bersal dari luar yaitu hutang.

Teori Trade-off menjelaskan suatu perusahaan menggunakan hutang semakin banyak tandanya semakin banyak risiko yang akan ditanggung perusahaan tersebut. Sehingga perusahaan yang mempunyai risiko bisnis yang tinggi harus lebih hati-hati dalam menggunakan hutang. Sehingga dapat diartikan bahwa perusahaaan yang memiliki tingkat profitablitas yang tinggi, maka hutang semakin rendah.

Seorang peneliti yaitu Ranti dan Christianti (2017) berhasil membuktikan adanya pengaruh $\mathrm{X} 4$ terhadap struktur modal secara negatif (-).

X5 Aktivitas Perusahaan

Aktivitas perusahaan dapat menggambarkan seberapa besar efektif manajemen suatu perusahaan dalam mempergunakan aktiva yang dimiliki, untuk operasional perusahan tersebut. Semakin tinggi TATO menunjukan semakin semakin efektifnya manajemen perusahaan dalam menggunakan aktiva tersebut guna menjalankan kegiatan operasional.

Tinggi rendahnya keadaan aset suatu perusahaan dapat menggambarkan tentang perputaran aset disuatu perusahaan serta keuntungan yang akan dicapai perusahaan dari perputaran aset tersebut. Tinggi nilai perputaran aset yang dimiliki perusahan menggambarkan bahwa semakin tinggi pula nilai penjualan terhadap nilai total aktiva.

Menurut Kritanti dkk (2019) perusahaan tidak harus dapat meningkatkan penjualan, tetapi harus lebih efesien dalam hal biaya operasional pada saat bersamaan.

Dengan demikian suatu aset yang tinggi menggambarkan tinggat aktivitas perusahaan yang tinggi maka hutang semakin rendah. Hal tersebut dikarenakan adanya perubahan total aktiva yang meningkat setiap tahunnya sehingga akan mempengaruhi pihak luar untuk menanamkan modalnya di perusahan tersebut.

\section{METODE PENELITIAN}

Penelitian ini didasarkan atas kerangka berpikir secara ilmiah yang digambarkan dalam gambar 2. 


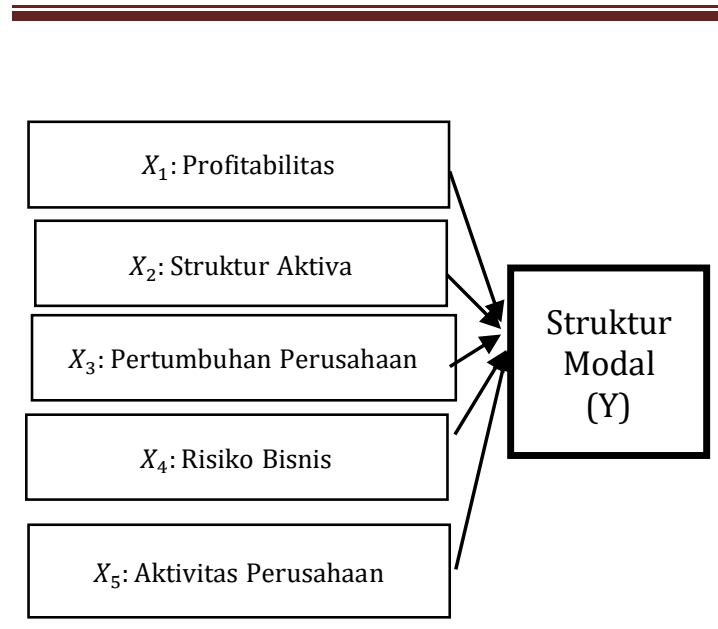

Gambar 2. Kerangka Pemikiran

Struktur Modal (DER). Stuktur modal dipilih untuk variabel dependen. Struktur modal diukur dengan DER. Peneliti menggunakan perhitungan DER untuk menghitung besar kecilnya perbandingan antara jumlah modal yang disediakan oleh kreditur dengan pemilik perusahan. Artinya guna mengetahui setiap rupiah modal sendiri dapat dijadkan sebagai jaminan hutang perusahaan tersebut.

$$
D E R=\frac{\text { Total Hutang }}{\text { Total Modal }}
$$

Profitabilitas (ROA). Menurut pendapat Harahap (2010:304) rasio profitablitas menggambarkan kemampuann suatu perusahan dalam memperolleh laba pada periode tersebut, melaui semua kemampuan dan sumber yang dimiliki perusahaan. Adapun perhitungan profitabilitas dapat diproksikan:

$$
R O A=\frac{\text { EAT }}{\text { Total Aset }}
$$

Struktur Aktiva ialah perbandingan kombinasi aktivatetap yang dimiliki perusahan dengan total aktiva perusahan. SA menjadi variabel yang terpenting dalam keputusan pendanaan suatu perusahaan, dikarenakan aset tetap yang dimiliki perusahaan dapat dijadikan sebagai jaminan bagi pihak kreditur. Adapun perhitungan SA:

$$
\mathrm{SA}=\frac{\text { Total Aset Tetap }}{\text { Total Aset }}
$$

Pertumbuhan Perusahan (GROWTH) menggambarkan adanya peningkatan penurunan dari total aktiva suatu perusahaan. Pertumbuhan.perusahaan mencermikan adanya peningkatan sumber daya berupa:aset yang dihitung sebagai persentase.perubahan aktiva suatu perusahaan,dari tahun tertentu. tehadap tahun sebelumnya.

\section{Growth : Total Aset $\mathrm{t}$ - Total Aset t-1 Total Aset $t-1$}

Risiko Bisnis (BEPR). Ialah suatu yang dihadapi suatu perusahan dalam menjalankan bisnisnya dalam periode tersebut. Seringkali terjadi dalam penggunaan hutang untuk tambahan modal.

$$
\text { BEPR }=\frac{\text { EBIT }}{\text { Total Aset }}
$$

Aktivitas Perusahaan (TATO). Aktivitas perusahaan mencerminkan seberapa besar efektifitas pihak manajemen .dalam menggunakan aktiva yang dimiliki perusahaan guna menjalankan ooperasi mereka.

$$
\text { TATO }=\frac{\text { Penjualan }}{\text { Total Aset }}
$$

Populasi dalm penelitian ini ialah pada perusahan sub.sektor perdagangan besar yang tertulis di BEI.periode 2013-2018. Teknik purposive sampling digunakan dalam penelitian/sehingga diperoleh 21 sampel perusahan dalam periode penelitian sebanyak 6 tahun, sehingga diperoleh sebanyak 126 data sampel.

Hasil pengujian statistic.deskriptif ini dipergunakan untuk menjelaskan dari tiaptiap variabel yang digunakan secara 

Vol. XVII No. 2 |Bulan Juli Tahun 2020

deskriptif. Berdasarkan pada Tabel 1 menunjukan hasil dari pengujian statistik deskriptif menunjukan variabel profitabilitas, pertubuhan perusahaan dan risiko bisnis memiliki nilai mean lebih kecil daripada nilai std. deviasi yang berarti data dari ketiga variabel tersebut bersifat bervariasi. Sedangkan variabel struktur aktiva dan HASIL PENELITIAN aktivitas perusahaan mempunyai nilai mean yang lebihbesar daripada nilai std.deviasi yang artinya datakedua variabel tersebut bersifat berkelompok.

TABEL 1. Statistik Deskriptif

\begin{tabular}{lcccrrr}
\hline & DER & ROA & SA & GROWTH & \multicolumn{1}{c}{$\boldsymbol{B E P R}$} & TATO \\
\hline Mean & 1.73418 & -0.00220 & 0.38838 & 0.25590 & 0.01090 & 1.48677 \\
\hline Max & 9.40190 & 0.41101 & 0.89872 & 23.04406 & 0.41060 & 5.40733 \\
\hline Min & -4.54666 & -1.21623 & 0.03994 & -0.55943 & -1.08945 & 0.00018 \\
\hline Std.Dev & 2.41843 & 0.15363 & 0.21086 & 2.05668 & 0.15272 & 1.21748 \\
\hline Sumber: data diolah penulis (2020) & & & & &
\end{tabular}

TABEL 2. Uji dari Regresi Data Panel

\begin{tabular}{|c|c|c|c|c|c|}
\hline & Prob. & $\begin{array}{c}\text { Prob. } \\
(F- \\
\text { Statistic) }\end{array}$ & $\begin{array}{c}\text { Cross } \\
\text { Section }\end{array}$ & $\begin{array}{c}\text { Adjusted } \\
\text { R- } \\
\text { Squared }\end{array}$ & $\begin{array}{c}\text { Coefficien } \\
t\end{array}$ \\
\hline Uji Chow & 0.0000 & - & - & - & - \\
\hline Uji Hausman & 0.1479 & - & - & - & - \\
\hline Uji $L m$ & - & - & 0.0000 & - & - \\
\hline Uji Simultan & - & 0,013040 & - & 0.095083 & - \\
\hline Uji Parsial & - & - & - & - & - \\
\hline Profitabilitas $(R O A)$ & 0.1591 & - & - & - & 6.103794 \\
\hline Struktur Aktiva $(S A)$ & 0.0377 & - & - & - & 1.306224 \\
\hline $\begin{array}{l}\text { Pertumbuhan } \\
\text { Perusahaan }(\text { GROWTH })\end{array}$ & 0.0039 & - & - & - & -0.218252 \\
\hline Risiko Bisnis $(B E P R)$ & 0.3813 & - & - & - & -3.927932 \\
\hline Aktivitas Perusahaan $(T A T O)$ & 0.1152 & - & - & - & -0.479874 \\
\hline
\end{tabular}

Sumber: data diolah penulis (2020)

\section{PEMBAHASAN}

Uji Chow berdasarkan hasil dari Uji Chow, nilai probability (Prob.) Crosssection F $0.0000<0.05$. Berdasarkan hasil pengujian tersebut menunjukan bahwa medel yang tepat untuk digunakan adalah Fixed Effect. Uji Hausman hasilnya nilai cross section random sebesar $0.1479>0.05$. Berdasarkan hasil pengujian tersebut menunjukan bahwa model yang tepat untuk digunakan Random Effect.

$$
\text { Uji LM dalam melakukan }
$$
pengujiannya menghasilkan Cross-section sebesar $0.0000<0.05$ artinya bahwa yangdigunakan adalah Random Effect. Jadi berdasarkan tiga pengujian yang sudah dilakukan, kesimpulannya yang cocok ialah Random Effect.

Dari data Tabel2, nilai(Prob Fstatistic) yaitu $0,013040<0,05$. Dengan besar signifikan dibawah 0,05 , berarti Ho ditolak $=$ semua variabel bebas secara bersamaan terdapat pengaruh signifikan terhaap struktur modal. Selain itu dari data Tabel 2 diketahui nilai Adjusted.R-squared senilai 0.095083 atau $9.5083 \%$. Hal ini mengindikasikan variabel bebas. dapat mempengaruhi variabel terikat senilai 0.095083 atau $9.5083 \%$ sedangkan sisanya 0,904917 atau $90,4917 \%$ dipengaruhi variabel lainnya.

Dari data Tabel 2 terlihat bahwa pengaruh antara (ROA.) terhadap (DER.) 

Vol. XVII No. 2 |Bulan Juli Tahun 2020

menunjukan,nilai keofesien senilai 6.103794 ,nilai probability senilai $0.1591>$ 0.05 artinya profitabilitas tidak mampu mempengaruhi struktur modal. Artinya tingkat profitabilitas sutau perusahaan yang rendah membuat struktur modal tidak berubah. Selajutnya, hasil pengujian antara struktur aktiva (SA) dengan struktur modal (DER), menunjukan nilai koefesien senilai 1.306224 dan nilai probability yang lebih kecil daripada tingkat signifikan 5\% yaitu 0.0377 , yang berarti variabel kedua yaitu struktur aktiva mampu mempengaruhi struktur modal secara positif (+). Artinya tinggi,rendahnya asetttetap yang dimiliki perusahan dapat mempengaruhi nilai dari struktur modal perusahan sub sektor perdagangan besar yang terdaftar di BEI periode 2013-2018.

Sama halnya dengan pengaruh antara (GROWTH ) terhadap (DER) dengan nilai koefesien -0.218252 dan nilai prob/bility $0.0039<0.05$, yang berarti variabel ketiga yaitu pertumbuhan perusahaan mampu mempengaruhi struktur modal secara negarif (-). Disebabkan karena perusahan yang mempunyai tingkat pertumbuhan perusahan tinggi yang memungkinkan memerlukan pendanaan dari luar untuk kegiatan operasi usahanya. Selanjutnya, hasil pengujan antara (BEPR) terhadap struktur modal (DER), menunjukan nilai koefesien - 3.9279,nilai probability senilai $0.3813>0.05$, artinya variabel ini tidak mampu mempengaruhi struktur modal. Hasil pengujian antara aktivitas perusahaan (TATO) terhadap struktur modal (DER), menunjukan nilai koefesien senilai - 0.479874 dan nilai probability senilai $0.1152>0.05$ mengartikan TATO tidak memiliki pengaruh terhadap variabel terikat.

\section{KESIMPULAN}

Berdasar, pada riset yang sudah dilaksanakan memperlihatkan jika struktur aktiva (SA.) dapat memperkirakan timbulnya struktur modal yang mengarah positif dan pertumbuhan perusahaan (GROWTH.) dapat memperkirakan munculnya struktur modal yang mengarah negatif. Namun, profitabilitas (ROA.), risiko bisnis (BEPR.), aktivitas perusahaan (TATO.) tidak memiliki dampak dalam memprediksi struktur modal.

Sebaiknya, manajemen suatu0perusahan harus lebih merumuskan kebijakan yang berkaitan dengan struktur modal suatu perusahan dan pihak perusahaan diharapkan agar mampu meningkatkan kinerjanya agar investor dapat lebih banyak menanamkan modalnya pada perusahaan tersebut. Penulis menyarankan kepada, investor untuk berhatihati dalam melakukan investasi dan memperhatikan faktor-faktor struktur aktiva dan pertumbuhan perusahaan agar terhindar dari risiko dalam melakukan struktur modal.

\section{DAFTAR PUSTAKA}

Ariani, N.K \& Wiagustini, N.L. (2017). Faktor-Faktor Yang Mempengaruhi Struktur Modal Perusahaan Property \& Real Estate Yang Terdaftar Di Bursa Efek Indonesia. EJurnal Manajemen Unud, Vol.6, No.6, 31683195.

Bigham \& Huston. (2011). Dasar-dasar Manajemen Keuangan (Edisi 11), penerjemah Ali Akbar Yulianto. Jakarta: Salemba Empat.

Firmanullah, N.,\& Darsono. (2017). FaktorFaktor Yang Mempengaruhi Struktur Modal di Perusahaan Indonesia (Pada Perusahaan Manufaktur yang Terdaftar dI BEI Tahun 2011-2014). Diponegoro Jurnal Of Accounting, Vol.6, No.3, 1-9.

Hery. (2016). Analisis Laporan Keuangan. Jakarta: PT.Grasindo.

Ismaida, P., \& Saputra, M. (2016). Pengaruh Pertumbuhan Penjualan, Profitabilitas, Ukuran. dan Aktivitas Perusahaan yang Terdaftar di BEI. Jurnal Ilmiah Mahasiswa 

Vol. XVII No. 2 |Bulan Juli Tahun 2020

Ekonomi Akuntansi (JIMEKA), Vol.1, No.1, 221-229.

Kamaludin. (2011). Manajemen Keuangan "Konsep Dasar Dan Penerapannya". Bandung:.Mandar maju.

Kasmir. (2010). Pengantar Manajemen Keuangan. Jakarta:.Kencana Prenada Media Grup.

Kristanti, F.T \& Iswandi. (2019)..The Differences of Company's Performance From Ceo Diversity. Polish Journal of Managemen Studies, Vol.19, No.2, 240-249.

Kristanti, F.T.,Rahayu, S., \& Isynuwardhana D. (2019)..Intergrating Capital Structure, Financial and NonFinancial Performance:
Distress Prediction of SMEs. Accounting and Finance Review. Vol.4, No.2, pp. 56-62.

Mardiyanto, H. (2009). Intisari Manajemen Keuangan. Jakarta:.Grasindo.

Ranti, A. M., \& Christianti, A. (2017). Pengaruh Size, Likuiditas, Profitabilitas, Risiko Bisnis dan Pertumbuhan Penjualan Terhadap Struktur Modal Pada Sektor Industri Properti yang Terdaftar di BEI. JRMB, Volume 12(1), pp. 13-24.

Suweta, N. M., \& Dewi, M. (2016). Pengaruh.Pertumbuhan Penjualan, Struktur. Jurnal Manajemen Unud, Volume 5(8), pp.5172-5199. 